\title{
MARGINAL REMARKS ON THE NEW TRENDS IN AMERICAN CONFLICTS LAW
}

\author{
KuRt H. NADELMANN**
}

A non-believer should perhaps not be honored with an invitation to a symposium on "New Trends in the Conflict of Laws," especially if he has a known interest in the history of that field of law. He may be tempted, as this one is, to spend his energy on testing the novelty of the new, parting from the foregone conclusion that everything worthy of trying has been tried before, under the same or other labels. Nor should the invitee accept the invitation easily if he knows that he never recovered from the shock of early discovery that, even for straight domestic law, taught method often leaves the judge at a loss; that, in reality, adjudication often requires the qualifications of a Chancellor from the times before equity was frozen. Thus he must count himself out as capable of unbiased view on methodological claims of the fail-safe type for a field where the facts to be evaluated are spread over two or more independent legal orders.

But non-believing may qualify as a trend, though not a new one, and comments from such side may be admissible under the first amendment. After all, infallibility of espoused or promoted method has been disclaimed by such eminent doctrinists as Story ${ }^{1}$ and Savigny, ${ }^{2}$ both, incidentally, counted among the practitioners and judges in Frederic Harrison's quip that conflict of laws "has owed more to judges than to professors." 3 Besides, if not blinded by his prejudice, the non-believer must recognize the high level of recent doctrinal and methodological discussion in the United States. And, if the better view is, as it may, that search for the best approach to conflicts problems must go on, whatever the chances of success in the sense of production of fail-safe formulae, the new chapters in the history of conflicts theory will illustrate once again the unruly character of the problems in conflict of laws.

In this country, new efforts in all directions were, of course, a necessity after the damage produced by the Vested Rights period and the over-simplifications of the first Restatement of the Law of Conflict of Laws and the confusion created by the Supreme Court's short-lived and rather dilettante attempts at settling interstate choice-

- J.U.D. I92I, Freiburg i. Br.; Licencié en droit 1934, Paris. Research Scholar, Harvard Law School; Adjunct Associate Professor of Law, New York University. Draftsman, Uniform Foreign Money-Judgments Recognition Act, 1962. Member, U.S. Observer Delegation to the Eighth (1956) and Ninth (I960) Sessions of the Hague Conference on Private International law.

${ }^{2}$ Joseph Story, Commentaries on the Conflict of Laws, Foreign and Domestic $\$ 38$, at 37 (1834).

2 Friedrich Carl von Savigny, Conflict of Laws 45 (2d ed., Guthrie transl. 1880).

${ }^{3}$ Harrison, Lectures on Conflict of Laws, 26 ForTwichtLy Rev. (N.S.) 727, 729 (1879), reprinted in Frederic Harrison, On Jurisprudence and the Conflict of Laws 145 (1919). Sec Nadelmann, Some Historical Notes on Doctrinal Sources of American Conflict of Laws, in IUS ET LEX-FestonnE Für MAX GutZWILLER 263, 276 (1959). 
of-law questions under the full faith command of the Constitution. ${ }^{4}$ And the harvest of the new activity has been rich indeed, in the new textbooks and law review writing, with court decisions beginning to take advantage of the rethinking which has taken place. Outstanding are, in particular, the case analyses from master hands, leaving no stone untouched and showing the complexities of conflicts problems.

More specifically, careful reading of statutes has been urged when their application to foreign occurrences is in question, which is in the best Story tradition, considering that the thirty-three year old Story made a first demonstration of it during his first year on the Bench, ${ }^{5}$ backing it up with an interesting quote from Casaregis. ${ }^{8}$ Helpful warnings have been given about "false" conflicts, a line in which the late E. M. Meijers pioneered with regard to the renvoi situation." The "continental" grouping of contacts has found favor, and the grouping can help appraisal even if a computer for rating the contacts may never be found. Again, the much talked-of governmental interest analysis can, and indeed must, be used in what the French call ordre public cases, that is, when, in the case before the court, the parties' expectations and other otherwise pertinent considerations must be overridden on public policy grounds strong enough to justify such non-consideration. Finally, if primacy of the forum law is urged by some, healthy counter-reaction has been produced, with the courts fully aware of their duty to render equal justice to the parties, however strong the itch of the homeward trend.

All this is helpful and would seem to suggest the correctness of the general approach chosen for the Restatement Second, namely, to indicate all possible angles that may have to be considered by the court, even if this leaves the court with little more than the Third of Huber's Maxims ${ }^{8}$ as guidance. At least will the judges not

"The writer's views on reading the full faith and credit clause with respect to statutes are found in Nadelmann, Full Faith and Credit to Judgments and Public Acts: A Historical-Analytical Appraisal, 56 Mich. L. REv. 33, 7I (1957).

"Van Rymsdyck v. Kane, 28 Fed. Cas. 1062 (No. I6,87I) (C.C. D.R.I. I8I2). See Nadelmann, Joseply Story's Contribution to American Conflict of Laws: A Comment, 5 AM. J. LEgaL Hist. 230, 239 (Ig6r).

${ }^{\circ} 28$ Fed. Cas. at 1064. The reference is to the Italian jurist's Discturstus legales de commercio, No. 130 (luca concursus creditorum) [Lucca bankruptcy] $\$ 15$ (1740), where it is said, in a discussion of whether the forum's bankruptcy statute applies to assets abroad, that local law governs the distribution of such assets, especially if the debts or contracts involved were incurred or entered into outside the territory of the statute: for "statutes must be assumed to deal with contracts made within and not outside their territory." Casaregis cites in support sources in Altogradus Senior's Consilia and Thuscus, as well as a Florentine decision of Sept. 22, 1724. For cases of "self-limitation" in old statutes, see Samuel Livermore, Dissertations on the Questions Which Arise From the Contrariety of the Positive Laws of Different States and Nations $\S 64$, at 62 (1828), where reference is made to Dumoulin, Ad lib. $I$, Codex, tit. $x$, in 3 Charles Dumoulin, Omnia Opera 556 (3d ed. Paris, I68I). Cf. Yntema, The Historical Bases of Private International Law, 2 AM. J. Comp. L. 297, 302, 304 (1953).

7 Under the influence of Meijers adopted, to varying extents, for (I) the Uniform Law of the Benelux Convention on Private International Law (art. I5 (2) and (3)), text in I INT'L \& CoMP. L.Q. (4th ser.) 426 (1952); (2) the Hague Convention of 195 I to Determine Conflicts Between the National Law and the Law of the Domicile, text in I AM. J. Comp. L. I, 2-3 (1952). See Meijers, The Benelux Convention on Private International Law, 2 AM. J. Comp. L. X, 2-3 (I953). Cf. Nadelmann, supra note 4 , at 80 .

8 "Sovereigns will so act by way of comity that rights acquired within the limits of a Government retain their force everywhere so far as they do not cause prejudice to the power or rights of such 
be misled, as they risked to be by some of the old "simple" rules of the first Restatement and would risk under advocated new ones of the same caliber, like the "Basic Rule of Validation" of which much has been heard.

Disturbing only in this most interesting academic activity is the pressure put by some on the courts that they substitute new for old doctrine. The task of the courts is adjudication of concrete issues before them. Embracing doctrines or methods is not part of it. The equity of the result reached needs to be shown, but this is all that is needed and keeps the court's duty within the humanly possible, any step beyond it inviting disaster.

Critique of opinion writing should perhaps be exercised more freely. The Bench may happily accept warnings. We will try to do it obliquely.

One of the neglected areas in comparative law work is comparison of the working methods of the judiciary, especially of opinion writing. Actually, knowledge of possible differences in this respect is necessary for the understanding of a foreign system. In countries with a flavor for doctrine, court opinions on conflicts often contain elaborate doctrinal supporting argument. In quite a few continental countries, the law puts secrecy on the vote on the decision. In other words, it is not made known whether the decision was unanimous. ${ }^{9}$ Thus in a case with a conflicts problem over which disagreement within the court may be presumed, doctrine is handed down by what, in fact, may be a bare majority of the court.

The French Supreme Court, which operates under the secret vote system, avoids almost entirely the passing out of doctrinal suggestions through its method of extremely short court opinions. A one-sentence opinion is common, the length of the sentence depending on the legal challenges made; and the sentence may be long indeed. The challenges are recited and the finding is added whether the law has, in fact, been violated. The "why" or "why not" is limited to the barest minimum. No reference is made to precedents or doctrinal writings. ${ }^{10}$

This technique of opinion writing which requires the ability of a master restater is most confusing to foreigners. They are, in particular, disturbed by the lack of reference to precedents. Have they been ignored? Here is the system. When the case comes up for review, which is of right, the chief judge assigns the case to a member of the court as reporter. After all briefs have come in, the reporter prepares a report which deals with precedents and doctrine as would any brief in a common law jurisdiction. The "open" part of the report is read at the argument, before the attorneys of the parties speak, so that they may address themselves to it. The "secret" part, which is the recommendation made by the reporter and his draft of a one-sentence opinion, are not revealed to the parties but

government or of its subjects." (transl.) Huber, De conflictu legum in diversis imperiis, in 2 Ulricus Huber, Praelectiones Juris civilis, lib. I, tit. 3 (1689); English translation of the sketch in note to Emory v. Grenough, 3 U.S. (3 Dall.) 369 (1797), and ERnest G. Lorenzen, Selected Artiches on THE CoNflict of LAws 136 (1947).

- See Nadelmann, The Judicial Dissent-Publication versus Secrecy, 8 AM. J. Comp. L. 415 (1959).

${ }^{10}$ See Frederick H. Lawson, Negligence in the Civil Law 233 (1950). Cf. Jan Gillis Wettrer, The Styles of Appelilate Judicial Opinions 28 (I960). 
are in the hands of the other members of the court. The open part of the report is, on occasion, but not very often, published in unofficial court reports. The decision itself, as published, gives the name of the presiding judge as well as of the reporter.

Obviously, a one-sentence opinion, even if a "perfect" restatement, is difficult to evaluate without help. Therefore, the two or three leading reporting law journals publish them with a critical annotation by an authority in the field. Precedents and the views of the authors are examined. The annotations furnish a running account of the status of the law.

More recently, a new twist was added to this "system," noticeable mainly in the conflicts field. One member of the court, an eminent scholar, who acts as reporter in the great majority of the conflicts cases, has taken to the habit of annotating for one of the leading law journals important cases in which he sat and was the reporter. The work for the report to the court of course facilitates the annotating. The same was done previously, also for conflicts cases, by a member of the court who had been a law professor and author of a textbook on conflicts before his appointment to the court. In the annotations, the voting is of course not revealed, which would be a violation of the judge's oath, but the reader may make his own guess on the position the reporter had taken.

What matters here is the fact that the one-sentence opinion which, normally, does not indicate the doctrinal or methodological approach chosen by the members of the court, finds itself, as it were, supplemented by a full analysis from the pen of the court member who had acted as reporter. Naturally, this analysis is "must" reading for the field. Whatever the desirability of this practice, an illuminating view is furnished on the question of opinion writing in a field as difficult as conflict of laws.

In a recent case which went up to the Supreme Court, a German domiciled in France had started divorce proceedings in the French courts against his German wife who was domiciled in Germany and had never been to France. The question before the Supreme Court was whether the French courts can take jurisdiction in such a case. Justifying the assumption of jurisdiction, the one-sentence opinion of the court ${ }^{11}$ refers to article 108 of the Civil Code which provides that the wife has no other domicile than that of the husband, the court calling the provision a necessary complement to the French rules on jurisdiction. The member of the court who was reporter has annotated the decision. ${ }^{12}$ In the annotation, an elaboration is found, among other things, on the governing French doctrine that the French venue provisions furnish bases for jurisdiction in the international sense and that the provisions on domicile are a necessary complement. Reference is made, in particular, to an earlier decision of the court ${ }^{13}$ in which the issue was whether the

${ }^{11}$ Dame S. v. S., Cour de Cassation (Ch. civ., Ist sect. civ.), Oct. 30, I962, [I962] Bulletin des arrêts de la Cour de Cassation I, 385 , No. 449; [ 1963 ] Recueil Dalloz Jurisprudence Iog.

12 G. Holleaux, Note, [1963] Recueil Dalloz Jurisprudence Io9.

${ }^{13}$ Dame Patino née de Bourbon v. Husband, Cour de Cassation (Ch. civ., sect. civ.), June 2I, 1948, [1948] Bullttin des arrêts de la Cour de Cassation 591, No. I89; [1949] Sircy I, I21, [1958] JurisClasseur Périodique II, No. 4422. 
plaintiff husband had his domicile in France and in which the provisions in the Code on domicile were relied upon by the court. That decision, also, had been annotated ${ }^{14}$ by the then reporter, the "professorial" member of the court.

We do not wish to suggest that either annotation goes beyond what the court itself said in its one-sentence opinion. Yet the reader, or at least this reader, is left with the impression of being given by the annotations a sketch of a doctrinal system as it may be found in a textbook, ${ }^{15}$ regarding venue, jurisdiction, the place of the provisions on domicile, and so on. This is of course most helpful but an American lawyer, at least, will feel uneasy, knowing as he does of the plight of the deserted wife under such a "system."16 Had the facts in the recent case been the other way around, with the German wife, domiciled in France, trying to sue before the French courts her German husband domiciled in Germany, article xo8 would have offered no help. The court was in the happy position to be able to fall back, for the case before it, on article ro8 to reach the desired result. It did not have to embrace a doctrine which will not "work" in the opposite case. Economy in supporting argument can be a virtue.

Generally speaking, and we think that this applies to all legal systems, especially when a court of last resort is involved and the result reached appears clearly equitable, the more the equity of the solution is stressed and the less doctrinal backing is added, the better is it in an area of the law for which a fail-safe doctrinal system or "method" is lacking. In some countries, important courts are composed of laymen. An example is the French commercial courts which have an enviable record. Their success is, in part, due to the fact that for obvious reasons in the briefs the "common sense" aspects of the issue must be stressed, and this approach is reflected in the opinions of the court. We think that the same should be attempted in the conflicts field, even when a "learned" court is addressed. Stressing the equity of the solution does not make the growth of law from precedent more difficult, and it lessens dangers of false generalizations.

While hard cases do arise, a large part of the conflicts decisions involve so-called easy cases which can be handled on a "common sense" basis without heavy doctrinal apparatus. Among the principally discussed "recent cases," the California decision Grant v. McAuliffe and the New York decision Babcock v. Jackson ${ }^{18}$ seem to us to belong to this class. Only doctrinal preconceptions can make them appear difficult. Application in these cases of "foreign" law would have produced a result which, in fairness, the parties in interest could not have expected, for the contact with the foreign territory had no significance under the circumstances of the cases. And we would be inclined to call "easy" also Haag v. Barnes, ${ }^{10}$ notwithstanding the fact that

\footnotetext{
14 P. L.-P. [Paul Lerebours-Pigeonnière], Note, [1948] Juris-Classeur Périodique II, No. 4422.

${ }^{15}$ Sec Paul Lerebours-Pigeonnière, Precis de droit international privé No. 397 , at 485 (8th ed. Loussouarn, I962).

${ }^{10}$ See Herbert F. Goodrich, Conflict of Laws 79 ( $3 \mathrm{~d}$ ed. 1949).

${ }^{17} 4 \mathrm{I}$ Cal.2d 859, 264 Pa.2d 944 (I953).

18 i 2 N.Y.2d 473 , I9I N.E.2d 279 (I963).

${ }^{10} 9$ N.X.2d 554, I75 N.E.2d 44I (I96I).
} 
the decision (or the supporting argument) has shocked one learned author. No interest worthy of protection was violated by holding as the court did.

In cases of the Kilberg ${ }^{20}$ and Pearson ${ }^{21}$ type where the result reached cannot, we think, be "justified" by any accepted standards of legal theory but is desirable as a "war" measure, the court should not engage either in attempts at doing the impossible but put the decision squarely on "public policy" grounds, showing carefully the existence of enough contacts with the forum to enable the court to apply its own law without violation of the requirements of due process of law (or of the full faith command if a sister state statute is involved). Clearly, the local law is applied as a "war" measure, and it is not "war" measures which general theory should attempt to cover. Indeed theory is likely to go wrong if built around extreme cases. The latter are the exception, fortunately.

"War" decisions of the Kilberg type almost always bring to the surface a factually intolerable condition. Commercial air traffic should not be allowed to go into territory with legislation giving substandard financial protection to passengers and their families in the case of an accident occurring there. The air line involved, if subject to suit elsewhere, must take account of the risk that foreign forums will apply their own law to protect those who had contacts with the forum by buying the ticket in the forum state. But this is open war, and it is meant to be. Internationally, the Warsaw Convention of $x 928$ had to be concluded to stop the wars and make international flying possible. ${ }^{22}$ That in a federal system with ample power to deal with the internal situation nothing should have been done to settle it, is shocking and even grotesque because of the otherwise minute federal regulation of interstate aviation. If the regulatory agencies think that they have no power, under existing law, to impose upon air lines minimum insurance of the passenger, they should long have recommended to the Congress the grant of such powers. Disappointing is the academic reaction to this type of litigation, with the discussion centering around doctrinal aspects of the choice-of-law problem instead of getting at the core of the problem, the need for action to remove it entirely.

But this reaction is only one example of a surprisingly narrow and technical approach chosen for consideration of internal conflicts problems in a federal system with ample means to do something about conflicts removal or conflicts settlement by use of federal power when there is or recourse to the machinery of the National Conference of Commissioners on Uniform State Laws in the absence or because of non-use of such power. Teaching materials on conflicts generally do not emphasize existing possibilities of conflicts prevention. The American Law Institute's effort is limited to a restatement of the law in the courts and the Commissioners on Uniform State Laws have postponed consideration of codification of conflicts rules until after the revision of the Restatement of Conflict of Laws has been completed. ${ }^{23}$

${ }^{80}$ Kilberg v. Northeast Airlines, 9 N.Y.2d 34, I72 N.E.2d 526 (I96r).

22 Pearson v. Northeast Airlines, 309 F.2d 553 (2d Cir. 1962 en banc).

${ }^{22}$ For today's inadequacies of the Warsaw Convention, see discussion in 1962 Procendings, Am. Soc' $Y$ INT'L LAW IIS et seq.

${ }^{33}$ See National Conference of Commissioners on Uniform State Laws, i955 Handbook i27, 13 I. 
While conflicts regulation is a poor second to conflicts removal and presents all the dangers of adoption of "easy" rules, usefulness of legislation at the right place cannot be questioned. The legislation to save wills from invalidity because of nonconformance with the formal requirements of the law of one of several "contacts" involved is an example. ${ }^{23 a}$

As a rare exception, the Cavers "Memorandum on Klaxon" for the American Law Institute's study of the Division of Jurisdiction between State and Federal Courts ${ }^{24}$ considers alternatives to the development of conflicts law by the courts. After discussion of the-more theoretical-possibility of prescribing conflicts rules by legislation under the full faith and credit clause, ${ }^{25}$ attention is turned to federal legislation prescribing interstate substantive rules, which the distinguished author considers the most fruitful of the alternative approaches. ${ }^{20}$ Three examples are given, the fatal airplane accident case exemplified by Kilberg, the situation which arises from defamation, trade libel, and unfair competition, and the case of civil liability arising from a nuclear accident. Specialists will rush to add their own examples. Even in a straight federal area, like bankruptcy, problems are allowed to survive which should go. Under the pressure of the depression, the difficulties stemming from local receiverships were removed by legislation now found in chapters ten and eleven of the Bankruptcy Act. But difficulties of the same type continue for insolvent decedents' estates with assets and debts in more than one state.77 Legislation to grant to the bankruptcy court discretionary power to take such cases has long been favored by the National Bankruptcy Conference ${ }^{28}$ but a mass catastrophe may be needed to produce action.

The problem is by no means the proper use of federal power alone or in the first place. In many instances, concerted action by the states, through the machinery of the Conference of Commissioners, is the better approach, even if federal legislation under full faith or the commerce clause is possible. An example in point is the experience with the Uniform Commercial Code. The "threat" of federal legislation, may we say, can have magic force.

The practical problem is that at no place is there a body surveying the general situation and trying to guide problems of this sort to their solution. Because of pressure from an individual or an organization, a specific topic may be taken up by the Commissioners but the Conference is no expert body on conflicts problems; nor

\footnotetext{
${ }^{2 s_{a}}$ Compare the new Wills Act, $\mathrm{I}_{963}$, Ir \& $\mathrm{I}_{2}$ Eliz. 2, c. 44, based on the Hague Convention of I960 on the Conflict of Laws relating to the Form of Testamentary Dispositions, 9 AM. J. Comp. L. 705 (1960), with the antiquated conflicts section 7 of the Model Exccution of Wills Act of I940, derived from section I of the Uniform Wills Act of I91o. 9 U.L.A. 421, 423 (I95I). See 4 EnNST RabeL, Conflict of Laws: A Comparative Study 296 (I958).

${ }^{24}$ Cavers, Change in Choice-of-Law Thinking and Its Bearing on the Klaxon Problem, in AxrenicuN Lap Institute, Study of the Division of JuRispiction Between State and Fedenal Courts I54 et seq. (Tent. Draft No. I, 1963 ).

$25 I d$. at 202 .

${ }^{20} \mathrm{Id}$. at 208 .

${ }^{27}$ See Nadelmann, Insolvent Decedents' Estates, 49 Mich. L. Rev. II29, II50, II60 (I951).

${ }^{28}$ Votes at the annual meetings of the Conference of 1957 and 1958.
} 
is it equipped to consider the alternative of possible federal action, if available. The Canadians may have done the right thing by providing for Dominion representation on their Conference of Commissioners. ${ }^{29}$ And when international angles need to be considered in addition to the interstate aspects, experts on the international part of the problem are lacking. Into this sort of situation the Conference has run several times lately. ${ }^{30}$ Not even for straight conflicts legislation is there cooperation with the American Law Institute. And for federal legislation all advisory machinery is lacking; the Administration normally sits back until substantial pressures are exercised. Under the circumstances it cannot surprise that no survey has ever been attempted of conflicts from the viewpoint of their removability under the present political climate by use of one or the other of the various available ways.

The lack of an organism to consider and handle problems with state, federal, and international aspects has become conspicuous. For years it was known that something has to be done to improve for our courts and litigants the possibilities of obtaining judicial assistance abroad. A commission was finally created by the Congress to attend to the problem, with representatives of both federal and state interests put on the commission and an advisory committee foreseen to provide the experts. Whether this scheme is a good one is too early to say. The Congress did not appropriate funds, which made outside financing necessary; the composition of the commission changed with the elections; and after four years spent exclusively on domestic law reform, consideration of the steps needed to be taken internationally has not even started. ${ }^{32}$ But new and even more important problems have arisen since. Under the sponsorship of an international institution which the United States has not joined as yet-a bill permitting the joining has been enacted ${ }^{33}$ -a Uniform Law on International Sales of Goods is in the making, with a diplomatic conference called for April Ig64 to consider the draft. Enactment of such a law elsewhere in the world will affect American interests. Yet, on this side of the Atlantic, no representative body has, so far, studied the draft and its implications. Only recently the Commissioners on Uniform State Laws became alarmed and decided to look into the matter, with the federal government sitting back, as far as can be judged, notwithstanding the fact that "Commerce with Foreign Nations" is involved.

Those who have given thought to the general problem, and this includes a

${ }^{20}$ For history, see "History" in the Proceedings of the Conference of Commissioners on Uniformity of Legislation in Canada.

${ }^{30}$ See, e.g., Uniform Foreign Money-Judgments Recognition Act, National Conference of Commissioners on Uniform State Laws, 9662 Handbook 242. Uniform Interstate and Internationál Procedure Act, id. at 219 .

${ }^{31}$ Act of Sept. 2, 1958, Pub. L. 85-906, 72 Stat. 1743. See Jones, Commission on International Rules of Judicial Procedure, 8 AM. J. CoMp. L. $34 \mathrm{I}$ (1959).

${ }_{32}$ See Comm'n on International Rules of Judicial Procedure, Fourth Ann. Rep. (I963), reprinted in H. Doc. No. 88, 88th Cong., Ist Sess. (1963).

${ }^{33}$ Stat. 775 (approved Dec. 30, 1963). 
Special Committee of the American Bar Association, ${ }^{34}$ think that an expert body needs to be set up, possibly by the President, to be available for study of work on conflicts removal undertaken on the international level. Such a body seems to be needed for consideration of problems of interstate conflicts avoidance or regulation as well. Often these problems are interrelated. Many unitary systems have an official or unofficial expert body for conflicts problems. In the United Kingdom, recourse is had to the Lord Chancellor's Committee on Private International Law, France has its Comité Français de Droit International Privé, Germany its Rat für internationales Privatrecht, and the Netherlands a Standing Governmental Commission which serves also as Steering Committee of the Hague Conference on Private International Law. Regional groups, like the Nordic Rad, Benelux, and the Common Market, fall back on the national expert bodies for joint work. With the American Law Institute, the National Conference of Commissioners, and learned International Law Societies available, a temporary body of experts to attend to the urgent problems can be set up easily. Experience will teach what kind of a permanent body needs to be established.

The simultaneous study of conflicts prevention problems on both the international and the interstate levels has great advantages. Experience on one level can be of value to the other. Contrary to a widespread belief, the internal American problem is not incomparable to others. Indeed the American experience with unification of law has been given increased attention abroad. But foreign experience is still widely unknown here. International and regional work, ${ }^{35}$ in particular the Scandinavian cooperation, ${ }^{36}$ furnish valuable material for comparison.

Almost seven centuries have passed of continuous methodological struggle for the "solution" of conflicts problems ${ }^{37}$ but some still call conflicts a "young" and underdeveloped field of the law. The conclusions suggested by the limited success of all efforts should not be ignored. The growing interest, in this century, in conflicts removal and in conflicts regulation is a reaction to the failures. It is a sound one. The achievements of the American Commissioners, in particular, are convincing proof of the large possibilities existing in this direction.

Much remains to be done to capitalize on the possibilities. In conflicts teaching, more attention should be given to conflicts removal. Teaching materials should be strengthened to convey a full view of the problems involved so that possibilities of conflicts removal, if there are any, can stand out. In a federal system with means to do something for conflicts removal, no effort should be spared in the direction

${ }^{34}$ Report of the American Bar Association Special Committee on Unification of Private Latu, 86 A.B.A. REP. 219 (196I), separately published by the American Bar Foundation in 196I; revicwed by the present writer in II AM. J. CoMp. I. II2 (I962).

${ }^{35}$ See the Year Books, "Unification of Law," of the International Institute for the Unification of Private Law.

${ }^{36}$ Ibid.; von Eyben, Nordic Legislative Co-operation, 6 Scandinavian STUdies in LaW 63 (1962).

${ }^{87}$ See Yntema, The Comity Doctrine, 2 Vom Deutschen ZuM Europaeischen Recht-Festschript Fuer Hans Doelle 65 (1963). 
of removal or control. The conflicts are sufficiently serious to do something about them.

The problems of the conflict of laws will not become any easier if a number of conflicts are removed from the battlefield. But this does not take away any of the benefits obtainable by conflicts removal. Consequently, in the opinion of at least one non-believer, reservation, in thinking about conflicts, of a little corner for the possibilities of conflicts removal can pay dividends and is recommended. No suggestion is made to look at conflicts removal as a "new" trend. 
